\section{ANALISIS KEPUASAN PADA PENGGUNA SISTEM TCS MENGGUNAKAN METODE END USER COMPUTING SATISFACTION \\ (STUDI KASUS: PT. TLK, BANDUNG)}

\section{SATISFACTION ANALYSIS ON TCS SYSTEM USERS USING END USER COMPUTING SATISFACTION METHODS (CASE STUDY: PT. TLK, BANDUNG)}

Rr. Rieka F. Hutami ${ }^{1}$, Dhea Ratna Camilla ${ }^{2}$

1,2 Fakultas Ekonomi dan Bisnis, Universitas Telkom, Bandung

rieka.hutami@gmail.com ${ }^{1}$, dearadeca@gmail.com²

\section{JURNAL \\ MANAJEMEN \\ INDONESIA}

Vol. 16 - No. 1

April 2016

Abstrak

Keunggulan bersaing bagi perusahaan dapat diperoleh dari kinerja perusahaan yang berkualitas, baik kinerja keuangan maupun kinerja aktifitas operasional sehari-hari. Salah satu faktor yang mempengaruhi kinerja aktifitas operasional adalah Teknologi Informasi (TI) yang terdiri dari perangkat keras (hardware), perangkat lunak ( software), maupun pengguna (user). Menindaklanjuti hal ini, PT TLK melakukan integrasi sistem dan bisnis proses melalui empat domain supporting system yang disebut OBCE. Penelitian ini, bertujuan melihat tingkat kepuasan pengguna di salah satu sistem informasi PT TLK yaitu sistem TCS, dimana pengguna sistem TCS merupakan pelanggan internal dari PT TLK. Hasil pengumpulan data diolah dengan menggunakan analisis deskriptif statistik dan analisis tingkat kepuasan. Pengolahan data menunjukkan bahwa dari kelima variabel yaitu variabel content, accuracy, format, ease of use dan timeliness menunjukkan bahwa responden merasa puas dengan kinerja dari sistem TCS saat ini dan menganggap bahwa kinerja sistem TCS tersebut sangat penting untuk ditingkatkan. Variabel yang memiliki nilai kinerja dan harapan paling rendah adalah variabel Ease of Use. Sementara terjadi perbedaan hasil analisis tingkat kepuasan yang menunjukkan variabel Accuracy yang memiliki GAP terbesar. Maka, kami lakukan konfirmasi kepada PT TLK melalui wawancara tidak terstruktur.

Kata Kunci : Sistem informasi, kepuasan, EUCS

\title{
Abstract
}

A competitive advantage for the company can be obtained from the company's performance quality, good financial performance and the performance of activities of daily operations. One of the factors that affect operational activities is an Information Technology (IT) including hardware, software, or User. PT TLK as one of the telecommunication companies in Indonesia, integrating their information systems and business processes through four domains supporting system called OBCE. This study aimed to see the level of user satisfaction in one information system PT TLK namely TCS system, where users of TCS system is the internal customers of PT TLK. The data collected were processed using descriptive statistical analysis and analysis of the level of satisfaction. Processing of the data showed that of the five variables, variable content, accuracy, format, ease of use and timeliness showed that the respondents were satisfied with the performance of the TCS system at the moment and assume that the TCS system performance is very important to be improved. The variable that has a value of performance and lowest expectation is variable Ease of Use. While there is a difference of analysis results showed levels of satisfaction Accuracy variables that have the greatest GAP. So, we do confirm to PT TLK through unstructured interviews.

Keywords : information system, satisfaction, EUCS

\section{Pendahuluan}

Industri yang memiliki pangsa pasar yang sensitif terhadap harga memiliki peluang untuk terlibat dalam perang harga (low price). Sebagai contoh, industri telekomunikasi 


\section{JURNAL}

MANAJEMEN

INDONESIA

Vol. 16 - No. 1

April 2016 yang memiliki jumlah pemain yang cukup banyak. Meskipun di satu sisi hal tersebut menguntungkan bagi konsumen, namun dampak lainnya yang paling dirasakan oleh konsumen terhadap perang harga adalah menurunnya kualitas layanan (quality of services), khususnya dalam hal koneksi (Pakar, 2015). Bagi perusahaan memang tidaklah mudah untuk menjaga kualitas dan memberikan harga yang murah kepada pelanggan di saat yang bersamaan. Namun, hal tersebut mungkin dilakukan apabila perusahaan mampu mengontrol proses produksi sehingga dapat meningkatkan kinerja perusahaan baik kinerja keuangan maupun kinerja aktifitas operasional sehari-hari. Salah satu faktor yang mempengaruhi kinerja aktifitas operasional adalah Teknologi Informasi (TI) yang terdiri dari perangkat keras (hardware),perangkat lunak (software), maupun pengguna (user) dinilai sangat penting agar terus dapat mempertahankan posisi di tengah bisnis yang sedang berjalan (Arthur et al, 2008).

PT TLK sebagai salah satu perusahaan telekomunikasi di Indonesia, menyadari hal tersebut dan telah melakukan simplifikasi, standarisasi dan integrasi sistem serta bisnis proses secara nasional melalui empat domain supporting system yang disebut OBCE, dengan terintegrasinya keempat sistem tersebut, PT TLK dapat melakukan manuver bisnis yang lincah, perbaikan tingkat layanan, revenue, dan tentunya cost assurance (www.pikiranrakyat.com).

Penelitian ini fokus pada pembahasan mengenai sistem TCS yang merupakan salah satu sistem informasi IT yang digunakan untuk fokus kepada pelayanan konsumen. Sistem TCS ini khusus digunakan untuk jenis konsumen Enterprise atau Corporate, pelanggan Wholesale dan pelanggan SME. Ketiga jenis pelanggan ini dikelola oleh tiga divisi yang berbeda antara lain; pelanggan Enterprise atau Corporate ditangani oleh Divisi A, pelanggan SME (Small Medium Enterprise) yang ditangani oleh Divisi B dan pelanggan Wholesale yang ditangani oleh Divisi C. Adanya sistem ini diharapkan perusahaan dapat mengelola pelanggan korporat dengan lebih baik serta meningkatkan kecepatan respon perusahaan atas segala permintaan (queries) yang pada akhirnya memiliki sistem informasi yang berkualitas akan memberikan keuntungan bagi perusahaan.

Menurut Doll dan Torkzadeh (dalam Arthur et al, 2008), kepuasan pengguna akhir sistem informasi dapat dijadikan sebagai salah satu ukuran keberhasilan suatu sistem informasi. Hal ini juga didukung oleh hasil riset yang dilakukan oleh DeLone and McLean (dalam Bijith dan Nilay, 2013). Selain itu, Doll dan Torkzadeh (dalam Pikkarainen, et al , 2008) juga menjelaskan bahwa kepuasan pengguna dapat menggambarkan keinginan untuk menggunakan sistem tersebut dan dengan mengukur kepuasan pengguna dapat diketahui jumlah pemakaian dalam sistem, namun hal ini tidak berlaku sebaliknya, dimana jumlah penggunaan tidak dapat dijadikan acuan untuk melihat kepuaasan pengguna.

Doll dan Torkzadeh (dalam Pikkarainen, et al , 2008) meneliti bahwa ada perubahan cara menggunakan sistem, bahwa di masa lalu pengguna dibantu oleh operator dalam menggunakan sistem informasi sehingga karena alasan inilah pengguna yang dimaksud dalam riset ini adalah pengguna akhir.

Doll dan Torkzadeh (dalam Arthur et al, 2008) mengembangkan model untuk mengukur kepuasan pengguna akhir yaitu End User Computing Satisfaction (EUCS) dimana model tersebut lebih menekankan kepuasan (satisfaction) pengguna akhir terhadap aspek teknologi, dengan melihat Content, Accuracy, Format, Easy of Use dan Timeliness. Berdasarkan pemaparan di atas, tujuan penelitian ini adalah mengetahui bagaimana kinerja yang akan dilakukan adalah "Analisis Tingkat Kepuasan Pengguna Sistem Dengan Metode End User Computing Satisfaction (Studi Kasus: Pengguna Sistem Aplikasi TCS PT TLK)".

\section{Landasan Teori}

\subsection{Pengertian Sistem Informasi}

Menurut Laudon (2007: 15), sistem informasi (information system) adalah sekumpulan komponen yang secara teknis saling berhubungan, mengumpulkan (atau mendapatkan), memproses, menyimpan, dan mendistribusikan informasi untuk membantu manajerial mengambil keputusan dan mengawasi dalam suatu organisasi. Definisi sistem informasi menurut Turban dan Reiner, (2009: 31), menambahkan satu fungsi lagi yaitu menyebarkan informasi dengan tujuan tertentu. 
Berdasarkan berbagai definisi diatas, dapat disimpulkan bahwa sistem informasi mencakup sejumlah komponen (manusia, komputer, teknologi informasi, dan prosedur kerja), ada sesuatu yang diproses (data menjadi informasi), dan dimaksudkan untuk mencapai suatu sasaran atau tujuan serta dapat digunakan untuk menyebarkan informasi.

\subsection{Komponen Sistem Informasi}

Menurut Turban dan Reiner (2009:31), komponen dasar dari sistem informasi adalah sebagai berikut;

1) Hardware atau perangkat keras merupakan perangkat seperti monitor, prosesor, keyboard dan printer yang apabila digunakan bersama dapat digunakan untuk menerima data atau informasi dan kemudian mengolah dan menampilkan.

2) Software atau perangkat lunak, merupakan program atau sekumpulan program yang memungkinkan perangkat keras memproses data.

3) A database merupakan sekumpulan file yang berisi data.

4) A network atau jaringan merupakan media penghubung baik wireline atau wireless yang memungkinkan komputer yang berbeda untuk saling berbagi sumber.

5) Procedures merupakan pedoman yang berisi instruksi tentang bagaimana mengkobinasikan atau mengoperasikan komponen diatas sehingga dapat mengolah informasi dan memunculkan output yang diharapkan.

6) People merupakan individu yang menggunakan perangkat keras, perangkat lunak serta berinteraksi sehingga memunculkan output.

\subsection{End User Computing Satisfaction}

Menurut Doll dan Torkzadeh (dalam Arthur, 2008: 32), definisi End User Computing Satisfaction dalam sebuah sistem informasi adalah mengevaluasi secara keseluruhan kepuasan para pengguna sistem informasi. Pengukuran kepuasan pengguna sistem ini dilakukan dengan cara membandingkan persepsi harapan dan kenyataan sebuah sistem informasi (Arthur et al, 2008: 32). Ruang lingkup pengguna menurut Doll dan Torkzadeh berbeda dengan yang dimaksud oleh Bijith dan Nalay (2013:441) yang mengemukakan bahwa ruang lingkup pengguna yang dimaksud disini adalah pengguna akhir. Metode EUCS dipilih dalam riset ini karena sesuai dengan tujuan riset yaitu mengevaluasi kepuasan pengguna akhir sistem TCS, selain itu metode EUCS juga dianggap metode yang efektif dalam mengevaluasi web sites (Bijith dan Nalay, 2013:442). Meskipun EUCS tidak memotret kepuasan sistem secara kesuluruhan dan hanya fokus pada satu aplikasi atau bagian tertentu dari sistem (Pikkarainen et al, 2006:161)

\subsection{Dimensi End User Computing Satisfaction}

Metode End User Computing Satisfaction atau EUCS menekankan evaluasi dari pengguna akhir terhadap aspek teknologi (Arthur et al, 2008: 32). Dimensi yang ada dalam EUCS terdiri dari isi (content), keakuratan (accuracy), format (Format), waktu (timeliness) serta kemudahan dalam menggunakan sistem (ease of use).

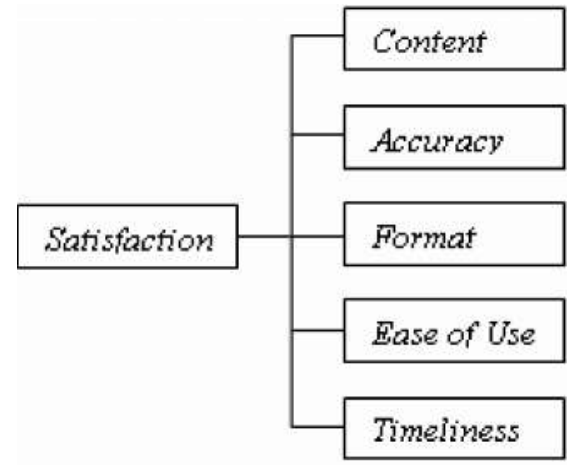

Gambar 1.

Model Evaluasi EUCS

Sumber:

Arthur et al (2008: 32)

Berikut ini adalah penjelasan tiap dimensi yang diukur dengan metode End User Computing Satisfaction menurut Doll dan Torkzadeh (dalam Arthur et al, 2008: 32-33):

1) Content (Isi). Dimensi ini menjelaskan ukuran kepuasan pengguna akhir dengan 


\section{JURNAL}

MANAJEMEN

INDONESIA

Vol. 16 - No. 1

April 2016

Tabel 1.

Skala Untuk Mengukur Persepsi dan Harapan Sistem TCS meilhat isi dari suatu sistem informasi, dimana isi meliputi modul atau fungsi-fungsi tertentu yang memiliki tujuan yang spesifik (Bijith dan Nalay, 2013:441) . Isi dalam sebuah sistem informasi haruslah sesuai dengan kebutuhan pengguna serta memiliki informasi terbaru. Hal ini dikarenakan semakin lengkap sebuah informasi maka dapat meningkatkan kepuasan pengguna.

2) Accuracy (Keakuratan). Keakuratan yang dimaksud di sini adalah ketepatan sistem dalam mengolah input serta menghasilkan sebuah informasi. Untuk mengecek apakah sebuah sistem memiliki tingkat keakurasian yang baik, dapatdilihat dari jumlah error yang dihasilkan ketika mengolah data.

3) Format (Format). Dimensi ini mengukur kepuasan pengguna akhir dalam menilai tampilan dan estetika dari antarmuka sistem. Tampilan yang menarik serta kemudahan dalam memahami dan menggunakan antar muka dapat meningkatkan kepuasan pengguna akhir dan dapat berpengaruh terhadap tingkat efektifitas pengguna.

4) Ease of Use (kemudahan dalam menggunakan sistem). Kemudahan dalam menggunakan sistem merupakan hal yang penting (Bijith dan Nalay, 2013:441). Hal ini dikarenakan kemudahan dalam menggunakan sistem meliputi keseluruhan proses dari awal sampai akhir yang terdiri dari proses memasukkan data, mengolah dan mencari informasi serta menampilkan data akhir yang akan digunakan oleh pengguna akhir.

5) Timeliness (waktu). Timeliness atau ketepatan waktu dalam menyajikan atau menyediakan informasi menjadi salah satu indikator kepuasan pengguna. Semakin cepat sebuah sistem mengolah input dan menghasilkan output dapat dijadikan tolak ukur penilaian apakah sistem tersebut tepat waktu atau real time.

\section{Metode Penelitian}

Penelitian deskriptif digunakan sebagai pendekatan dalam penelitian ini. Teknik pengumpulan data yang digunakan adalah teknik pengumpulan data primer dengan menggunakan kuesioner dan wawancara. Pada kuesioner digunakan skala Likert untuk mengukur persepsi dan harapan responden tentang sistem TCS dengan bentuk skala yang digunakan adalah sebagai berikut:

\begin{tabular}{|c|c|c|}
\hline Persepsi & Harapan & Skor \\
\hline Sangat Puas (SP) & Sangat Penting (SP) & 4 \\
\hline Puas (P) & Penting (P) & 3 \\
\hline Tidak Puas (TP) & Tidak Penting (TP) & 2 \\
\hline Sangat Tidak Puas (STP) & Sangat Tidak Penting (STP) & 1 \\
\hline
\end{tabular}

Dalam penelitian ini, jumlah populasi yaitu jumlah karyawan Divisi B (Business Service) yaitu 223 orang dan Divisi A (Enterprise Service) yaitu 709 orang, sehingga total jumlah populasi adalah 932 orang. Kemudian untuk menentukan jumlah sampel, digunakan rumus slovin sehingga didapat 90 responden sebagai sampel minimum dan pemilihan responden menggunakan teknik sampling Convinience.

\subsection{Uji Validitas Dan Relibilitas}

Untuk menguji kehandalan kuesioner, peneliti melakukan uji validitas dan reliabilitas dengan menyebarkan kuesioner kepada 30 orang responden. Untuk membantu perhitungan validitas yang lebih akurat, dalam penelitian ini digunakan software IBM SPSS Statistics 20. Penelitian ini menggunakan taraf signifikansi 0,05 nilai $r$ tabel untuk penelitian ini adalah 0,361 . Berikut adalah hasil uji validitas dan reliabilitas. 


\begin{tabular}{|c|c|c|c|c|}
\hline \multirow{2}{*}{ Var. } & $\begin{array}{c}\text { No. } \\
\text { Item }\end{array}$ & $\begin{array}{c}\text { r_hitung } \\
\text { Tingkat } \\
\text { Kepuasan }\end{array}$ & $\begin{array}{c}\text { r_hitung } \\
\text { Tingkat } \\
\text { Kepentingan }\end{array}$ & Ket. \\
\hline \multirow{2}{*}{ X1 } & 1.1 & 0.760 & 0.660 & Valid \\
\cline { 2 - 5 } & 1.2 & 0.695 & 0.763 & Valid \\
\hline \multirow{2}{*}{ X2 } & 1.3 & 0.480 & 0.603 & Valid \\
\cline { 2 - 5 } & 1.4 & 0.791 & 0.683 & Valid \\
\hline \multirow{2}{*}{ X3 } & 1.5 & 0.746 & 0.616 & Valid \\
\cline { 2 - 5 } & 1.6 & 0.826 & 0.644 & Valid \\
\hline \multirow{2}{*}{ X4 } & 1.7 & 0.858 & 0.684 & Valid \\
\cline { 2 - 5 } & 1.8 & 0.823 & 0.602 & Valid \\
\hline \multirow{2}{*}{ X5 } & 1.9 & 0.893 & 0.766 & Valid \\
\cline { 2 - 5 } & 1.10 & 0.849 & 0.805 & Valid \\
\hline
\end{tabular}

JURNAL

MANAJEMEN

INDONESIA

Vol. 16 - No. 1

April 2016

Berdasarkan Tabel 2, dapat ditarik kesimpulan bahwa semua item pernyataan baik tingkat kepuasan maupun tingkat kepentingan seluruhnya dinyatakan valid karena $r$ hitungnya $>0.361$. Hal ini bisa terjadi dikarenakan pada saat membuat item pernyataan pada kuesioner peneliti melakukan wawancara pendahulu dengan pihak perusahaan untuk mengkonfirmasi setiap item pertanyaan yang ada dikuesioner yang kemudian membuat pertanyaan di dalam kuesioner mudah dipahami oleh responden.

Menurut Sekaran dalam Priyatno (2012: 187) reliabilitas kurang dari 0,6 adalah kurang baik, sedangkan 0,7 dapat diterima dan di atas 0,8 adalah baik. Hasil perhitungan uji reliabilitas menunjukkan bahwa nilai alpha cronbach untuk kepuasan sebesar 0,945 serta nilai alpha cronbach untuk kepentingan sebesar 0,912. Dikarenakan keduanya memiliki nilai $>0,8$, maka dapat disimpulkan kuesioner tersebut memiliki tingkat kehandalan yang baik.

Sedangkan untuk mengetahui persepsi responden maka data akan dianalisis menggunakan analisis deskriptif statistik dimana masing-masing variabel akan dikategorikan berdasarkan kriteria skor seperti yang terlihat pada tabel dibawah ini.

\begin{tabular}{|c|c|c|l|}
\hline No & Persentase & Kriteria Kinerja & \multicolumn{1}{c|}{ Kriteria Harapan } \\
\hline 1 & $25 \%-43,75 \%$ & Sangat Tidak Baik & Sangat Penting(SP) \\
\hline 2 & $>43,75 \%-62,5 \%$ & Tidak Baik & Penting (P) \\
\hline 3 & $>62,5 \%-81,25 \%$ & Baik & Tidak Penting (TP) \\
\hline 4 & $>81,25 \%-100 \%$ & Sangat Baik & Sangat Tidak Penting (STP) \\
\hline
\end{tabular}

Tabel 3.

Kriteria Interpretasi Skor

\subsection{Analisa Tingkat Kepuasan}

Setelah melakukan analisis statistik deskriptif, analisis dapat dilanjutkan dengan melakukan analisis tingkat kepuasan untuk menjawab rumusan masalah. Tingkat kepuasan merupakan perbandingan antara penilaian performansi sistem dengan harapan pengguna. Tingkat kepuasan atau sering disebut dengan tingkat kesesuaian ini menunjukan kualitas sistem yang dirasakan oleh pengguna.

$$
T k i=\frac{X i}{Y i} \times 100 \%
$$

Keterangan:

$$
\begin{aligned}
\text { Tki } & =\text { Tingkat kepuasan responden } \\
\mathrm{Xi} & =\text { Skor penilaian kinerja sistem } \\
\mathrm{Yi} & =\text { Skor penilaian harapan pengguna }
\end{aligned}
$$

Tingkat kesesuaian/kepuasan dikatakan sempurna apabila menunjukan nilai 100\%, tapi apabila nilai tingkat kesesuaian/kepuasan responden terhadap kinerja sistem yang dihasilkan kurang dari $100 \%$, berarti menunjukan adanya kesenjangan antara performansi sistem yang diberikan dengan harapan yang diinginkan pengguna sistem (Rangkuti, 2002).

\section{Hasil Dan Pembahasan}

\subsection{Karakteristik Responden}

Sebelum melakukan analisis dengan data, peneliti mencoba memaparkan karakteristik 
responden berdasarkan beberapa kriteria, diantaranya berdasarkan unit kerja, usia serta lamanya menggunakan sistem TCS.

\section{JURNAL}

MANAJEMEN

INDONESIA

Vol. 16 - No. 1

April 2016

Gambar 2.

Karakteristik Responden

Berdasarkan Unit Kerja

Gambar 3.

Karakteristik Respon-

den Berdasarkan Usia

Gambar 4.

Karakteristik Responden Berdasarkan

Pengalaman Menggunakan Sistem TCS

\section{1) Karakteristik Responden Berdasarkan Unit Kerja}

Seperti yang pernah disebutkan sebelumnya bahwa pengguna sistem TCS terdiri dari tiga unit. Hasil dari analisa responden menunjukkan jumlah responden terbesar diwakili oleh responden yang bekerja di Divisi A (Enterprise Service) yaitu sebesar $66 \%$ atau sebanyak 59 orang karyawan dan Divisi B yaitu sebesar $34 \%$ atau sebanyak 31 orang karyawan. Hal ini memungkinkan karena dari segi jumlah karyawan, Divisi A memiliki jumlah karyawan lebih banyak dari divisi B seperti yang ditunjukkan pada gambar 4.1 berikut:

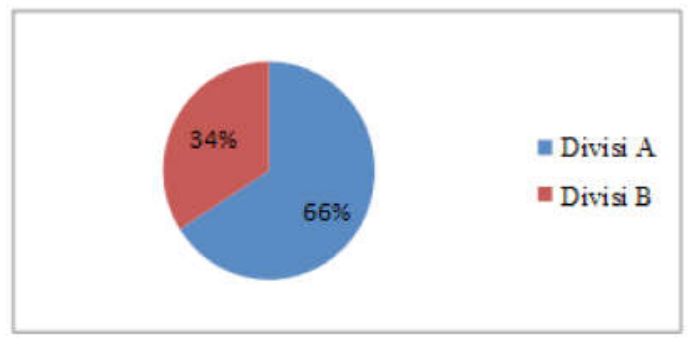

2) Karakteristik Responden Berdasarkan Usia

Gambar 3 menunjukkan bahwa pengguna sistem terbanyak berada pada rentang usia > 45 tahun yaitu sebesar $54 \%$ atau sebanyak 49 orang karyawan, diikuti responden berusia 31 - 45 tahun yaitu sebesar $30 \%$ atau sebanyak 27 orang karyawan, dan responden berusia < 30 tahun yaitu sebesar $16 \%$ atau sebanyak 14 orang karyawan. Distribusi karakteristik responden berdasarkan usia dapat dilihat pada gambar berikut :

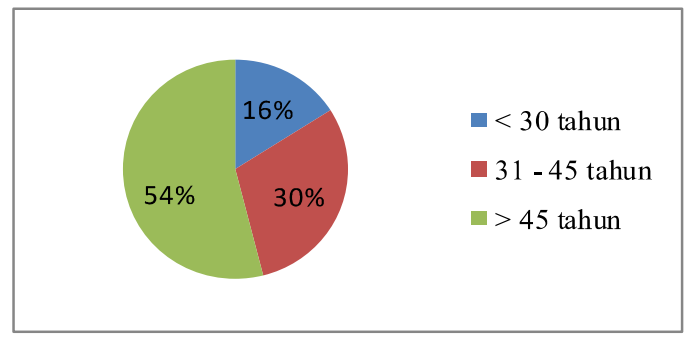

3) Karakteristik Responden Berdasarkan Pengalaman Menggunakan SistemTCS

Apabila melihat data karakteristik responden pada gambar 4, diketahui bahwa rata-rata responden sudah cukup lama menggunakan sistem ini, dimana jumlah responden terbesar diwakili oleh responden yang memiliki pengalaman menggunakan sistem TCS selama > 3 tahun yaitu sebesar $45 \%$ atau sebanyak 41 orang karyawan, diikuti oleh karyawan yang memiliki pengalaman $1-2$ tahun yaitu sebesar $23 \%$ atau sebanyak 21 orang karyawan, lalu karyawan dengan pengalaman $<1$ tahun dan $2-3$ tahun masing-masing sebesar $16 \%$ atau sebanyak 14 orang karyawan.

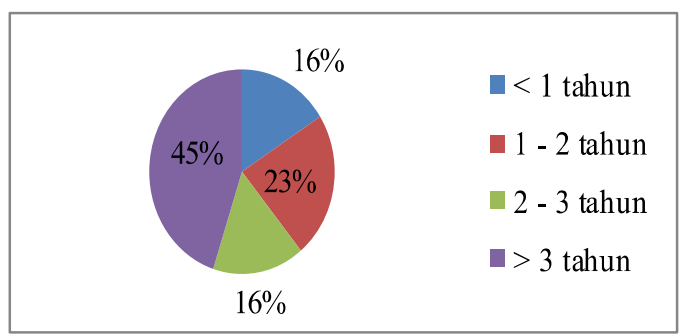


1) Penilaian dan Harapan Pengguna Mengenai Isi (Content) Sistem TCS

Variabel Content mengukur dua indikator yaitu kelengkapan modul dan pengolahan sistem informasi. Setiap indikator terdiri dari satu item pertanyaan. Berikut tabel yang menunjukkan bagaimana penilaian dan harapan pengguna mengenai konten dari sistem TCS.

\begin{tabular}{|c|l|c|c|c|}
\hline \multirow{2}{*}{$\begin{array}{c}\text { No } \\
\text { Item }\end{array}$} & \multicolumn{1}{|c|}{ Pernyataan } & $\begin{array}{c}\text { Skor Total } \\
\text { (Kinerja) }\end{array}$ & $\begin{array}{c}\text { Skor Total } \\
\text { (Harapan) }\end{array}$ & $\begin{array}{c}\text { Skor } \\
\text { Ideal }\end{array}$ \\
\hline \multirow{2}{*}{1.1} & $\begin{array}{l}\text { Sistem TCS memiliki modul } \\
\text { yang sesuai dengan } \\
\text { kebutuhan }\end{array}$ & 286 & 321 & \multirow{2}{*}{360} \\
\cline { 2 - 4 } 1.2 & $\begin{array}{l}\text { Informasi diproses sesuai } \\
\text { dengan proses bisnis }\end{array}$ & $\mathbf{7 9 , 4 4 \%}$ & $89,17 \%$ & \\
\cline { 3 - 4 } & Jumlah Skor Total & $\mathbf{2 8 4}$ & 319 & \\
\hline & Jumlah Skor Ideal & $\mathbf{5 7 0}$ & $88,61 \%$ & \\
\hline & Persentase Skor & $\mathbf{7 9 , 1 7 \%}$ & $\mathbf{8 8 , 8 9 \%}$ & \\
\hline
\end{tabular}

Tabel 4 diatas menunjukkan penilaian responden terhadap kinerjasistem TCS untuk variabel Content sebesar $79,17 \%$ dan apabila diinterpretasikan ke dalam diagram kriteria angka tersebut berada pada rentang $62,5 \%-81,25 \%$ atau berada pada kategori Tinggi. Sedangkan, tingkat kepentingan terhadap kinerja sistem TCS untuk variabel Content adalah sebesar $88,89 \%$ dan apabila diinterpretasikan ke dalam diagram kriteria angka tersebut berada pada rentang $81,25 \%$ - $100 \%$ atau berada pada kategori Sangat Tinggi.

2) Penilaian dan Harapan Pengguna Mengenai Keakuratan (Accuracy) Sistem TCS

Variabel Accuracy mengukur persepsi responden tentang kemampuan sistem TCS dalam mengolah data secara akurat serta konsistensi dari output yang dihasilkan sistem. Tabel 5 menunjukkan tingkat kinerja sistem TCS untuk variabel Accuracy adalah sebesar $74,31 \%$ dan apabila diinterpretasikan ke dalam diagram kriteria angka tersebut berada pada rentang $62,5 \%-81,25 \%$ atau berada pada kategori Baik. Sementara, data juga menunjukkan tingkat kepentingan terhadap performansi sistem TCS untuk variabel Accuracy adalah sebesar 87,5\% dan apabila diinterpretasikan ke dalam diagram kriteria angka tersebut berada pada rentang $81,25 \%$ - 100\% atau berada pada kategori Sangat Tinggi.

\begin{tabular}{|c|c|c|c|c|}
\hline $\begin{array}{c}\text { No } \\
\text { Item }\end{array}$ & Pernyataan & $\begin{array}{c}\text { Skor Total } \\
\text { (Kinerja) }\end{array}$ & $\begin{array}{l}\text { Skor Total } \\
\text { (Harapan) }\end{array}$ & Skor Ideal \\
\hline \multirow[b]{2}{*}{1.3} & \multirow{2}{*}{$\begin{array}{l}\text { Tidak ada Error pada } \\
\text { proses pengolahan data } \\
\text { pada sistem TCS }\end{array}$} & 247 & 312 & \multirow{4}{*}{360} \\
\hline & & $68,61 \%$ & $86,67 \%$ & \\
\hline \multirow[b]{2}{*}{1.4} & \multirow{2}{*}{$\begin{array}{l}\text { Output yang dihasilkan } \\
\text { oleh sistem TCS akurat } \\
\text { dan konsisten }\end{array}$} & 288 & 318 & \\
\hline & & $80 \%$ & $88,33 \%$ & \\
\hline & Jumlah Skor Total & 535 & 630 & \\
\hline & Jumlah Skor Ideal & 720 & 720 & \\
\hline & Persentase Skor & $74,31 \%$ & $87,5 \%$ & \\
\hline
\end{tabular}

3) Penilaian dan Harapan Pengguna Mengenai Format Sistem TCS

Tabel 6 menunjukkan bahwa responden merasa interface dan kemudahan akses dari sistem TCS baik yang ditunjukkan dengan persentase untuk variabel Format adalah sebesar 77,5\% dan apabila diinterpretasikan ke dalam diagram kriteria angka tersebut berada pada rentang $62,5 \%-81,25 \%$ atau berada pada kategori Tinggi. Berikut tabel yang menunjukkan bagaimana penilaian dan harapan pengguna mengenai Format konten dari sistem TCS.
JURNAL

MANAJEMEN

INDONESIA

Vol. 16 - No. 1

April 2016

Tabel 4.

Penilaian dan Harapan

Pengguna Mengenai

Content Sistem TCS

Tabel 5 .

Penilaian dan Harapan

Pengguna Mengenai

Accuracy Sistem TCS 


\section{JURNAL}

\section{MANAJEMEN}

INDONESIA

Vol. 16 - No. 1

April 2016

Tabel 6

Penilaian dan Harapan

Pengguna Mengenai

Format Sistem TCS

Tabel 7

Penilaian dan Harapan

Pengguna Mengenai

Ease of Use Sistem TCS

Tabel 8

Penilaian dan Harapan

Pengguna Mengenai

Timeliness Sistem TCS

\begin{tabular}{|c|l|c|c|c|}
\hline \multirow{2}{*}{$\begin{array}{c}\text { No } \\
\text { Item }\end{array}$} & \multicolumn{1}{|c|}{ Pernyataan } & $\begin{array}{c}\text { Skor Total } \\
\text { (Kinerja) }\end{array}$ & $\begin{array}{c}\text { Skor Total } \\
\text { (Harapan) }\end{array}$ & $\begin{array}{c}\text { Skor } \\
\text { Ideal }\end{array}$ \\
\hline \multirow{2}{*}{1.5} & Interface (Antarmuka) sistem TCS user friendly & 261 & 306 & \multirow{2}{*}{360} \\
\cline { 3 - 4 } & & $72,5 \%$ & $85 \%$ & \\
\cline { 1 - 3 } 1.6 & $\begin{array}{l}\text { Sistem TCS dapat diakses dari perangkat yang } \\
\text { telah tersedia dalam perusahaan }\end{array}$ & $\mathbf{2 9 7}$ & 313 & \\
\cline { 3 - 4 } & Jumlah Skor Total & $82,5 \%$ & $86,94 \%$ & \\
\hline & Jumlah Skor Ideal & $\mathbf{7 2 0}$ & 619 & \\
\hline & Persentase Skor & $\mathbf{7 7 , 5 \%}$ & $\mathbf{8 5 , 9 7 \%}$ & \\
\hline
\end{tabular}

Sementara, data juga menunjukkan tingkat kepentingan terhadap performansi sistem TCS untuk variabel format adalah sebesar $85,97 \%$ dan apabila diinterpretasikan ke dalam diagram kriteria angka tersebut berada pada rentang $81,25 \%-100 \%$ atau berada pada kategori Sangat Tinggi.

4) Penilaian dan Harapan Pengguna Mengenai Ease of Use Sistem TCS

Variabel Ease of Use mengukur persepsi responden terhadap kemudahan serta kenyamanan dalam menggunakan sistem TCS. Tabel 7 menunjukkan bahwa responden merasa mudah dan nyaman dalam menggunakan sistem TCS, hal ini dibuktikan dengan nilai persentase sebesar $72,22 \%$ dimana angka tersebut berada pada rentang 62,5\% - 81,25\% atau berada pada kategori Tinggi. Responden juga merasa kemudahan dan kenyamanan dalam menggunakan sistem sangat penting, hal ini ditunjukkan dengan nilai persentase tingkat kepentingan untuk variabel ini adalah sebesar $85 \%$ dan apabila diinterpretasikan ke dalam diagram kriteria angka tersebut berada pada rentang $81,25 \%-100 \%$.

\begin{tabular}{|c|l|c|c|c|}
\hline $\begin{array}{c}\text { No } \\
\text { Item }\end{array}$ & \multicolumn{1}{|c|}{ Pernyataan } & $\begin{array}{c}\text { Skor Total } \\
\text { (Kinerja) }\end{array}$ & $\begin{array}{c}\text { Skor Total } \\
\text { (Harapan) }\end{array}$ & $\begin{array}{c}\text { Skor } \\
\text { Ideal }\end{array}$ \\
\hline \multirow{2}{*}{1.7} & $\begin{array}{l}\text { Sistem TCS mudah } \\
\text { digunakan }\end{array}$ & 260 & 309 & \\
\cline { 3 - 4 } & & $72,22 \%$ & $85,83 \%$ & \multirow{2}{*}{360} \\
\cline { 2 - 4 } 1.8 & $\begin{array}{l}\text { Sistem TCS nyaman } \\
\text { untuk digunakan }\end{array}$ & 260 & 303 & \\
\cline { 3 - 4 } & Jumlah Skor Total & $522 \%$ & $84,17 \%$ & \\
\hline & Jumlah Skor Ideal & 720 & 720 & \\
\hline & Persentase Skor & $\mathbf{7 2 , 2 2 \%}$ & $\mathbf{8 5 \%}$ & \\
\hline
\end{tabular}

5) Penilaian dan Harapan Pengguna Mengenai Timeliness Sistem TCS

Variabel Timeliness mengukur persepsi responden terhadap kemampuan sistem TCS dalam menyajikan informasi serta keterbaharuan (update) isi dari informasi tersebut. Tabel 8 menunjukkan bahwa responden sangat puas terhadap kecepatan dan keterbaharuan informasi yang diberikan oleh sistem TCS. Hal ini dibuktikan dengan perolehan skor kepuasan sebesar 75,14\% berada pada rentang 62,5\%$81,25 \%$ atau berada pada kategori Tinggi. Sementara, kecepatan dan keterbaharuan informasi yang diberikan oleh sistem juga sangat penting yang ditunjukkan dengan persentase skor sebesar $85,83 \%$ yang artinya sangat penting karena berada pada rentang $81,25 \%-100 \%$.

\begin{tabular}{|c|c|c|c|c|}
\hline $\begin{array}{c}\text { No } \\
\text { Item }\end{array}$ & Pernyataan & $\begin{array}{l}\text { Skor Total } \\
\text { (Kinerja) }\end{array}$ & $\begin{array}{l}\text { Skor Total } \\
\text { (Harapan) }\end{array}$ & $\begin{array}{l}\text { Skor } \\
\text { Ideal }\end{array}$ \\
\hline \multirow[b]{2}{*}{1.9} & \multirow{2}{*}{$\begin{array}{l}\text { Informasi yang } \\
\text { terdapat dalam sistem } \\
\text { TCS dapat diperoleh } \\
\text { dengan cepat }\end{array}$} & 267 & 308 & \multirow{4}{*}{360} \\
\hline & & $74,17 \%$ & $85,56 \%$ & \\
\hline \multirow{5}{*}{1.10} & \multirow{2}{*}{$\begin{array}{l}\text { Informasi dalam } \\
\text { sistem TCS up to date }\end{array}$} & 274 & 310 & \\
\hline & & $76,11 \%$ & $86,11 \%$ & \\
\hline & Jumlah Skor Total & 541 & 618 & \\
\hline & Jumlah Skor Ideal & 720 & 720 & \\
\hline & Persentase Skor & $75,14 \%$ & $85,83 \%$ & \\
\hline
\end{tabular}

Hasil analisa persepsi responden terhadap kinerja dan harapan dari masing-masing variabel di atas dapat diolah lebih lanjut untuk mendapatkan nilai kepuasan yang sesungguhnya dari responden. Hal ini dilakukan dengan cara membandingkan kinerja dan harapan dari sistem TCS seperti yang ada pada tabel 9 berikut ini. 


\begin{tabular}{|c|c|c|c|c|}
\hline Variabel & $\begin{array}{c}\text { Skor } \\
\text { Kinerja }\end{array}$ & $\begin{array}{c}\text { Skor } \\
\text { Harapan }\end{array}$ & $\begin{array}{c}\text { Tingkat } \\
\text { Kepuasan (\%) }\end{array}$ & GAP / Selisih \\
\hline Content & 570 & 640 & $89,06 \%$ & $10,94 \%$ \\
\hline Accuracy & 535 & 630 & $84,92 \%$ & $15,08 \%$ \\
\hline Format & 558 & 619 & $90,15 \%$ & $9,85 \%$ \\
\hline Ease of Use & 520 & 612 & $84,97 \%$ & $15,03 \%$ \\
\hline Timeliness & 541 & 618 & $87,54 \%$ & $12,46 \%$ \\
\hline Total & $\mathbf{2 7 2 4}$ & $\mathbf{3 1 1 9}$ & $\mathbf{8 7 , 3 3 \%}$ & $\mathbf{1 2 , 6 7 \%}$ \\
\hline
\end{tabular}

\section{JURNAL \\ MANAJEMEN \\ INDONESIA}

Vol. 16 - No. 1

April 2016

Berdasarkan Tabel 9, total tingkat kepuasan yang dirasakan oleh pengguna sistem aplikasi TCS sehubungan dengan performansi sistem aplikasi TCS adalah sebesar 87,33\% dengan gap/selisih sebesar 12,67\%. Variabel Format memiliki gap/selisih terkecil yaitu sebesar 9,85\%, sedangkan gap/selisih terbesar ada pada variabel Accuracy, yaitu sebesar $15,08 \%$.

\section{Kesimpulan Dan Saran}

Hasil analisis statistik deskriptif menunjukkan bahwa responden merasa bahwa kinerja dari sistem baik, hal ini dikarenakan kelima variabel yaitu accuracy, content, ease of use, format, dan timeliness berada di kategori Puas. Kemudian responden juga berharap di masa yang akan datang performansi dari sistem ini akan terus ditingkatkan, hal ini ditunjukkan dengan nilai persentase skor harapan semua variabel rata-rata yang berada di rentang sangat penting. Namun, jika kita analisa lebih dalam masing-masing variabel yang memiliki nilai kinerja dan harapan paling rendah adalah variabel Ease of Use. Kemudian, variabel yang memiliki kinerja paling tinggi serta harapan paling tinggi adalah Content.

Untuk melihat lebih jelas hasil penelitian ini, digunakan hasil analisis tingkat kepuasan yang membandingkan antara kinerja saat ini dengan harapan. Secara keseluruhan tingkat kepuasan responden terhadap aplikasi sistem TCS adalah sebesar sebesar 87,33\% dengan gap/selisih sebesar $12,67 \%$. Artinya, pada saat memberikan layanan sistem TCS kepada pengguna masih ada beberapa aspek yang harus diperbaiki jika melihat tingkat kepuaasan yang ideal adalah $100 \%$. Sehingga perlu dilihat tingkat kepuasan masing-masing variabel. Hasil analisis juga menunjukkan Variabel Format memiliki gap/selisih terkecil yaitu sebesar 9,85\%, sedangkan gap/selisih terbesar ada pada variabel Accuracy, yaitu sebesar 15,08\%. Artinya, jika ingin meningkatkan kepuasan pengguna, dapat dilakukan perbaikan terlebih dahulu pada variabel Accuracy.

Dari hasil analisis deskriptif dan hasil analisis tingkat kepuasan terjadi perbedaan hasil, dimana jika melihat hasil analisis deskriptif kita fokus pada variabel Ease of Use. Namun, jika melihat hasil tingkat kepuasan variabel Accuracy yang memiliki gap terbesar. Maka, kami lakukan konfirmasi kepada PT TLK melalui wawancara tidak terstruktur. Dari hasil konfirmasi tersebut diketahui bahwa variabel Ease of Use dan variabel Accuracy merupakan dua hal yang sering menimbulkan komplain lisan ataupun pertanyaan. Masih banyak pertanyaan yang timbul seputar penggunaan aplikasi TCS dan juga masih banyak komplain terkait error pada saat pengolahan datanya.

Oleh sebab itu, saran peneliti adalah mengevaluasi sistem TCS terutama yang menyangkut pengolahan data supaya dapat menghilangkan error lalu melakukan program pelatihan untuk penggunaan aplikasi TCS. Selain itu, helpdesk yang selalu ada untuk menjawab pertanyaan seputar penggunaan aplikasi TCS juga dapat membantu proses pemahaman pelanggan terhadap aplikasi tersebut.

Penelitian ini, merupakan penelitian empiris yang masih memiliki banyak kekurangan, salah satunya kekhususan terhadap objek tertentu dalam hal ini aplikasi TCS. Namun peneliti yakin bahwa penelitian ini bisa menambah khasanah pengetahun kita. Untuk penelitian selanjutnya, peneliti menyarankan untuk meneliti tentang pengaruh kepuasan terhadap kinerja perusahaan. Hal ini merujuk pada pendapat DeLone dan McLean yang menyatakan bahwa kepuasan pengguna sistem akan berpengaruh terhadap kinerja individu dan pada akhirnya akan berpengaruh terhadap kinerja perusahaan. 


\section{Daftar Pustaka}

\section{JURNAL}

MANAJEMEN

INDONESIA

Vol. 16 - No. 1

April 2016
Abidin, Fahmi. (2013). 2014, Industri Telekomunikasi Diprediksi Tumbuh 6\%8\%. [Online]. Tersedia pada: http://mix.co.id/headline/2014-industritelekomunikasi-diprediksi-tumbuh-6-8. [Diakses: 20 Desember 2015)

Arthur., Eka, Andry., Robert., Abdurachman, Edi. (2008). Analisis Tingkat Kepuasan Pengguna Sistem Informasi Underwriting Pada PT Tugu Pratama Indonesia. Jurnal Piranti Warta, 11(1), 28-44.

Bairi, Jayachandra., Manohar, B. Murali. (2011). Critical Success Factors In Gaining User Customer Satisfaction In Outsourced IT Services. Journal of Enterprise Information Management, 24(6), 475-493.

Bijith Marakarkandy and Nilay Yajnik, (2013),"Re-examining and empirically validating the End User Computing Satisfaction models for satisfaction measurement in the internet banking context", International Journal of Bank Marketing, Vol. 31 Iss 6 pp. 440 - 455. [Online]. http://dx.doi. org/10.1108/IJBM-06-2013-0051. [12 Mei 2016]

Dinh Thai Hoang, Barbara Igel, Tritos Laosirihongthong. (2006).The impact of total quality management on innovation. International Journal of Quality \& Reliability Management, Vol. 23 Iss 9, pp. $1092-1117$.

Infusion 2008, Transformasi Telkom di Bidang TI. [Online]. http://www.pikiranrakyat.com/node/81448. [4Agustus 2012]

Pakar.(2015). Pakar: Persaingan Industri Telekomunikasi Kian Tidak Sehat.

Pikkarainen Kari, Tero Pikkarainen, Heikki Karjaluoto dan Seppo Pahnila, (2006),"The measurement of end-user computing satisfaction of online banking services: empirical evidence from Finland", International Journal of Bank Marketing, Vol. 24 Iss 3 pp. 158 - 172. [Online].http://dx.doi. org/10.1108/02652320610659012.[12 Mei 2016].

Prajogo, Daniel I., Amrik S. Sohal.(2004).Transitioning from total quality management to total innovation

Priyatno, Duwi. (2012). Cara Kilat Belajar Analisis Data Dengan SPSS 20. Yogyakarta: Andi.

Rangkuti, Freddy (2002). Measuring Customer Satisfaction: Teknik Mengukur dan Strategi Memingkatkan Kepuasan Pelanggan plus Analisis Kasus PLN-JP. Gramedia Pustaka. Jakarta.

Riduwan, \& Sunarto. (2010). Pengantar Statistika. Bandung: Alfabeta.

Turban, Efraim., Rainer, R. Kelly. 2009. Introduction to Information Systems: Enabling and Transforming Business. Second Edition. United States: John Wiley \& Sons Pte Ltd. 
JURNAL

MANAJEMEN

INDONESIA

Vol. 16 - No. 1

April 2016 
JURNAL

MANAJEMEN

INDONESIA

Vol. 16 - No. 1

April 2016

Jurnal Manajemen Indonesia 